den. Deze "balans" toont ook een schuld op lange termijn (,10 jarige $2 \%$ debentures, vervallende in 1956), welke van het saldo van de activa minus schulden op korte termijn wordt afgetrokken, alvorens tot de "net assets" te geraken. Ook hier zijn de fracties van de dollar weggelaten. Echter mist men de vergelijking met de cijfers van het voorgaande jaar, welke in het Australische voorbeeld de aandeelhouders een inzicht geeft in de veranderingen in de samenstelling van het vermogen sinds de laatste balansdatum.

Melbourne, September 1947.

\title{
DIFFERENTIATIE IN HET ACCOUNTANTSBEROEP
}

door M. C. Wintersteyn

Het artikel van Prof. van der Schroeff in het M.A.B. van October j.1. heb ik met zeer veel genoegen gelezen. Met de daarin voorkomende opvattingen van de hooggeleerde schrijver ben ik het volkomen eens. Het geeft mij echter aanleiding tot enkele opmerkingen, welke meer van algemene aard zijn. En wel de volgende:

1e. Prof. v. d. Schroeff noemt bij het bespreken van de differentiatie in het accountantsberoep twee verschillende functies, n.l. de controlerende en de adviserende. Even wordt het administratief-organisatorische element naar voren gebracht, maar het organiseren van de administratie zelf wordt tot de adviserende functie gerekend. Hier nu zou ik verder willen gaan. Ik zou willen onderscheiden de controlerende, de organiserende en de adviserende functie. En hiermede loop ik parallel met de opleiding van het N.I. V. A., dat immers kent de controleleer (dus de voorbereiding tot de controlerende functie) de inrichtingsleer (de voorbereiding tot de organiserende functie) en de bedrijfshuishoudkunde (de voorbereiding tot de adviserende functie). De kennis van de administratieve methoden, de administratieve techniek, en vooral van de hulpmiddelen bij de administratie is zo veelomvattend geworden, dat deze niet meer als onderdeel van het algemene beroep kan worden beschouwd, maar dat een bijzondere ontwikkeling in die richting nodig is geworden, wil men deze functie volledig kunnen uitoefenen.

Dat ik deze organiserende functie noem tussen de controlerende en de adviserende is met opzet. Immers de organisator van de administratie moet bij zijn organisatie als doel voor ogen hebben, dat, wat de advise rende accountant aan gegevens van de administratie verwacht. Maar hij moet bij zijn organisatie er tevens rekening mede houden, dat de controlerende accountant zijn functie naar behoren zal kunnen uitoefenen.

Op dit punt wil ik dus verder gaan dan de hooggeleerde schrijver en een drietal functies onderkennen.

2e. De schrijver spreekt over de openbare accountant. Slechts even noemt hij de interne. Dit zal geen opzet zijn, en geen bepaalde bedoelin $\exists$ hebben, en toch gevoel ik mij lichtelijk teleurgesteld.

Wanneer tegenwoordig over accountants wordt gesproken, wanneer reglementen van arbeid worden behandeld, wordt steeds gesproken over de ,public-accountant". De interne accountant is een beetje het stiefkind. En dat is verkeerd. 
Aan de interne accountant worden wat ontwikkeling, bekwaamheid en betrouwbaarheid betreft precies dezelicle eisen gesteld als aan de openbare. En nu juist de differentiatie bewijst dat zo goed.

Ik geloof niet, dat er lang over behoeft te worden gepraat, dat het voor de adviserende en de organiserende functie, wat de uitoefening van deze functies betreft, geen verschil maakt, of men met een interne of met een externe accountant heeft te maken. Van beiden wordi precies hetzelfde verwacht.

En nu wat de controlerende betreft. Natuurlijk mag een interne accountant geen rapport uitbrengen aan derden. Daarover zijn we het eens. Een certificatie van een jaarrekening in een te publiceren jaarverslag mag alleen door een externe accountant worden ondertekend.

Maar wil dat nu zeggen, dat aan de interne accountant in de controlerende functie lagere eisen worden gesteld dan aan de externe? Geenszins. Het enige verschil is, dat de externe accountant verantwoordelijkheid draagt tegenover een andere gemeenschap dan de interne. De externe accountant plaatst zijn handtekening tegenover ,het publiek". Dat zou dus de hele gemeenschap zijn.

Stel hier tegenover de accountant, die door een kartel werd aangesteld om de kartelleden te controleren. Dit is in wezen een interne accountant, want $z$ ijn rapport is alleen bedoeld voor zijn werkgever, het kartelbestuur. Maar mag men aan hem lagere eisen steller? Neen immers. En zo is het ook met de concern-accountant, de interne accountant, die de onderdelen van het concern controleert en daarover rapport uitbrengt aan het bestuur, hetzij directie, hetzij commissarissen, van het concern. Ook aan hem worden de eisen even hoog gesteld.

Voor de beide laatste functionarissen is de "geneenschap" een kleinere. Maar vermoedelijk is die een veel meer geinteresseerde! De ",gemeenschap" waar tegenover de public-accountant staat dient een veel grotere te $z \mathrm{ijn}$, ware het niet, dat jammer genoeg het publiek zo weinig van zijn verklaring weet. Immers, hoe weinig effectenbezitters zullen zich hebben afgevraagd, of de door hen gekochte effecten zijn uitgegeven door een onderneming, welke door een externe accountant wordt gecontroleerd? Het is jammer, maar toch is de kring van ,.derden", die naar de handtekening van de externe accountant vraagt, zeer klein.

Mijn overtuiging is dan ook, dat de eisen van vakbekwaamheid en betrouwbaarheid voor externe en interne accountant even hoog moeten worden gesteld, en dat er tussen beiden, wat reglementering betreft, geen enkel verschil mag worden gemaakt, en dat men daarom in vele gevallen beter alleen kan spreken van ,de accountant".

Alleen ........ het rapporteren wordt beperkt tot de gemeenschap, voor welke de rapportering is bedoeld.

3e. En tenslotte, waar de hooggeleerde schrijver opmerkt, dat arbeidsanalyse, tijd- en bewegingsstudies, routing enz. niet des accountants $z i j n$, heeft hij groot gelijk. Maar anderzijds moeten zij, die tot hun taak de genoende studies rekenen, zoals de raadgevende ingenieurs, zich onthouden van het optreden op administratief-organisatorisch terrein.

En ik meen, dat wat dit laatste betreft, er meer aanleiding tot vrees voor overschrijding van het eigen arbeidsterrein bestaat, dan wat de accountant aangaat. 


\section{Naschrift}

Ik ben de heer Wintersteyn erkentelijk voor zijn opmerkingen, die mij de gelegenheid geven op enige punten in te gaan, om zodoende mogelijke misvattingen van mijn bedoelingen weg te nemen.

In mijn opstel heb ik ten aanzien van de beroepsuitoefening van de openbare accountant, controlerende en adviserende functie onderscheiden. Ik moge aannemen, dat ik de laatste functie zo gesteld heb, dat bij de lezer geen twijfel heeft bestaan, dat daarin ook de werkzaamheden van organisatorische aard zijn vervat. Doordat mijn aandacht in hoofdzaak gericht was op de bedrijfsecononische adviezen van de openbare accountant, heb ik geen noodzaak gevoeld om een verder gaande splitsing in functies te maken door, gelijk de heer Wintersteyn dat wil, de organisatorische arbeid op het gebied van administratie als afzonderlijke functie te stellen. Ik zou niet gaarne zien, dat men uit de omstandigheid, dat $\mathrm{ik}$ slechts enkele woorden aan de administratief-organisatorische functie van de accountant heb gewijd, zou afleiden, dat ik een differentiatie van dit deel van de werkzaamheden van weinig betekenis zou achten. Het tegendeel is waar. De eisen van de deskundigheid en ervaring, die aan de administratief-organisatorische arbeid worden gesteld, zijn zo veelomvattend, dat reeds op deze grond een verbizondering kan worden overwogen en voor sommige gevallen doelmatig moet worden geacht. Het vraagstuk echter, waarop ik in mijn opstel de aandacht heb willen vestigen, n.l. de mogelijkheid van een collisie van adviserende en controlerende functie bij het samengaan van beide functies, ligt er ten aanzien van deze administratief-organisatorische arbeid niet. Hierin is dan ook de reden gelegen, dat ik - bij de beperkingen, die ik bij een zo omvangrijk probleem mijzelve had op te leggen - na enkele vermelding verder aan de organiserende functie ben voorbijgegaan.

De heer Wintersteyn voelt zich teleurgesteld, dat ik in mijn opstel de interne accountant slechts terloops heb genoend. Ook op dit punt wil ik gaarne reageren, opdat iedere mogelijkheid van een verkeerde uitleg van mijn bedoelingen wordt weggenomen.

Het vraagstuk, dat ik heb aangevat, is dat van de verbizondering van het accountantsberoep in de zin van de zelfstandige beroepsuitoefening. omdat daar een war probleem ligt, dat om oplossing vraagt. Wanneer ik bij mijn uiteenzettingen niet over de interne accountant heb gesproken, is dit, omdat dit vraagstuk voor de interne accountant anders ligt en ook een geheel andere betekenis heeft dan voor de openbare accountant, omdat zijn functie een andere is. Toch zal de heer Wintersteyn in mijn opstel een aanwijzing kunnen vinden omtrent een verbizondering van de werkzaamheden van de interne accountant in de uitoefening van zijn functie in het bedrijf, waar ik schreef (blz. 290, bovenaan), dat de grootst mogelijk objectiviteit bij de controle de voorwaarde stelt. dat de controleur geen rechtstreekse bemoeienis heeft met de uitvoering, noch een aandeel heeft in de constituerende leiding.

Het staat geheel buiren discussie, dat de normen van deskundigheid en betrouwbaarheid, waaraan de arbeid van de interne accountant moet worden gemeten, andere zouden zijn dan die voor de openbare accountant. Maar nu dit punt in discussie is gebracht, wil ik nadrukkelijk zeggen, dat naar mijn oordeel in de eisen en ontwikkeling, bekwaamheid en betrouwbaarheid geen verschil moet worden genaakt. Men zou de betekenis van de functie van interne accountant miskennen, wanneer 
men - zoals schrijver het uitdrukt - deze accountant als het stiefkind zou behandelen. Maar bij dat al mag niet over 't hoofd worden gezien. dat bij vele vraagstukken in de regeling van het beroep de interne accountant een andere plaats inneemt dan zijn collega in de vrije beroepsuitoefening. En men moet er dan ook geen miskenning van een interne accountant in zien, indien voor deze regelingen in het bizonder de aandacht naar de openbare accountant uitgaat.

Wat de laatste opmerking betreft inzake de overschrijding van hat eigen arbeidsterrein, had ik mijn artikel geschreven voor andere deskundigen dan de accountants, bijv, voor de raadgevende ingenieurs, ik zou dezelfde opmerking hebben gemaakt, wellicht in meer stringente bewoordingen. Zullen de accountants goed doen om zich bij de afbakening van hun werkterrein de beperkingen op te leggen in overeenstemming met hun bizondere deskundigheid, het geldt niet minder voor alle andere deskundigen, die men op het terrein van de voorlichting van het bedrijf ontmoet. Inzonderheid wel voor de raadgevende ingenieurs, die naar de ervaring leert hun bemoeienis somtijds uitstrekken op een arbeidsgebied, dat beter aan de accountants ter bewerking kan worden overgelaten.

H. J. VAN DER SCHROEFF

\section{DE BELASTINGDESKUNDIGE EN DE ORGANISATIE VAN HET ACCOUNTANTSKANTOOR}

doot F. J. Prause

Dit onderwerp wordt door Drs A. J. F. Reyn in het M.A.B. van October 1947 ter sprake gebracht. De conclusies, waartoe de heer Revn komt, zijn in het kort de volgende:

a. de accountant behandelt alleen belastingzaken voor z.g. controleclienten, zodat slecht gecontroleerde cijfers aan de belastinginspecties overgelegd worden;

b. indien voor de belastingzaken een belastingdeskundige aan het accountantskantoor verbonden wordt, heeft deze persoon slechts een adviserende taak; de leider van het accountantskantoor tekent de stukken en draagt de verantwoordelijkheid;

c. het is ongewenst dat het accountantskantoor z.g. belastingclienten heeft. De naam van het accountantskantoor wekt de indruk, dat de in deze gevallen overgelegde gegevens ook gecontroleerd zijn, wat niet het geval is. Er wordt dus een te groot vertrouwen gewekt, tenzij zeer nadrukkelijk wordt vermeld, dat de cijfers niet gecontroleerd zijn. Laatstebedoelde vermelding wordt niet gewenst geacht;

d. de meest rationele oplossing acht de heer Reyn dan het stichten van een zelfstandig belastingadvieskantoor ten gerieve van de belastingclienten.

Met de conclusies onder $\mathrm{a}, \mathrm{b}$ en $\mathrm{c}$ kan ik het volkomen eens zijn. De oplossing vervat in conclusie $\mathrm{d}$ bevredigt mij echter niet. Stel accountant $A$ te $O$ heeft een accountantskantoor onder de naam: Accountantskantoor A. Hij opent nu het "O'sche Bureau voor Belastingzaken". 